\title{
Plasminogen Deficiency Significantly Reduces Vascular Wall Disease in a Murine Model of Type IIa Hypercholesterolemia
}

\author{
Takayuki Iwaki ${ }^{1,2, *,+} \oplus$, Tomohiro Arakawa ${ }^{2,+}$, Mayra J. Sandoval-Cooper ${ }^{1}$, Denise L. Smith ${ }^{1}$, \\ Deborah Donahue $^{1}$, Victoria A. Ploplis ${ }^{1}$, Kazuo Umemura ${ }^{2}$ and Francis J. Castellino ${ }^{1}$ \\ 1 The W. M. Keck Center for Transgene Research, The Department of Chemistry and Biochemistry, \\ University of Notre Dame, Notre Dame, IN 46556, USA; msandoval@nd.edu (M.J.S.-C.); \\ Denise.L.Smith.804@nd.edu (D.L.S.); Deborah.L.Donahue.16@nd.edu (D.D.); vploplis@nd.edu (V.A.P.); \\ fcastell@nd.edu (F.J.C.) \\ 2 Department of Pharmacology, Hamamatsu University School of Medicine, Hamamatsu 431-3192, Japan; \\ arakawa@hama-med.ac.jp (T.A.); umemura@hama-med.ac.jp (K.U.) \\ * Correspondence: tiwaki@hama-med.ac.jp; Tel.: +81-53-435-2271 \\ + These two authors equally contributed to this work.
}

Citation: Iwaki, T.; Arakawa, T.; Sandoval-Cooper, M.J.; Smith, D.L.; Donahue, D.; Ploplis, V.A.; Umemura, K.; Castellino, F.J. Plasminogen Deficiency Significantly Reduces Vascular Wall Disease in a Murine Model of Type IIa Hypercholesterolemia. Biomedicines 2021, 9, 1832. https://doi.org/ 10.3390 /biomedicines 9121832

Academic Editor: Jesus M. Martin-Campos

Received: 8 November 2021

Accepted: 29 November 2021

Published: 4 December 2021

Publisher's Note: MDPI stays neutral with regard to jurisdictional claims in published maps and institutional affiliations.

Copyright: (C) 2021 by the authors Licensee MDPI, Basel, Switzerland. This article is an open access article distributed under the terms and conditions of the Creative Commons Attribution (CC BY) license (https:// creativecommons.org/licenses/by/ $4.0 /$ )

\begin{abstract}
The fibrinolytic system has been implicated in the genesis and progression of atherosclerosis It has been reported that a plasminogen $(\mathrm{Pg})$ deficiency $\left(\mathrm{Plg}^{-/}\right)$exacerbates the progression of atherosclerosis in $A p o e^{-/-}$mice. However, the manner in which Plg functions in a low-density lipoprotein-cholesterol (LDL-C)-driven model has not been evaluated. To characterize the effect of $\mathrm{Pg}$ in an LDL-C-driven model, mice with a triple deficiency of the LDL-receptor (LDLr), along with the active component (apobec1) of the apolipoprotein B editosome complex, and $\mathrm{Pg}\left(\mathrm{L}^{-/-} / \mathrm{A}^{-/-} / \mathrm{Plg}^{-/-}\right)$, were generated. Atherosclerotic plaque formation was severely retarded in the absence of $\mathrm{Pg}$. In vitro studies demonstrated that LDL uptake by macrophages was enhanced by plasmin (Pm), whereas circulating levels of LDL were enhanced, relative to $L^{-/-} / A^{-/-}$mice, and VLDL synthesis was suppressed. These results indicated that clearance of lipoproteins in the absence of LDLr may be regulated by $\mathrm{Pg} / \mathrm{Pm}$. Conclusions: The results from this study indicate that Pg exacerbates atherosclerosis in an LDL-C model of atherosclerosis and also plays a role in lipoprotein modification and clearance. Therefore, controlling the Pg system on macrophages to prevent foam cell formation would be a novel therapeutic approach.
\end{abstract}

Keywords: LDL receptor; apobec-1; plasminogen; atherosclerosis; foam cells

\section{Introduction}

Atherosclerosis has been described as a "self-perpetuating" inflammatory disease, which progresses in discrete stages and involves a number of cell types and effector molecules. Upregulation of low-density lipoprotein (LDL) levels, which is the most frequent type IIa hypercholesterolemia, is one of the most important factors causing atherosclerosis in humans. Human liver synthesizes and secretes very low density lipoprotein (VLDL) nascent particles. Each VLDL particle consists of 50-80\% triglyceride (TG), 5-15\% cholesterol ester (CE), 10-20\% phospholipids, and one molecule of apolipoprotein (apo) B100. Nascent VLDL particles in blood acquire apoE and apoCII from high-density lipoprotein (HDL) to form mature VLDL particles. After hydrolysis of TG by lipoprotein lipase and/or hepatic lipase, VLDL is converted to LDL, which in turn delivers CE via LDL receptor (LDLr)-mediated endocytosis [1]. LDLr subsequently binds to the C-terminal region of the single-chain 4536 amino acid residue, apoB100. Amino acid sequences encompassing 3147 to 3157 and 3359 to 3367 of apoB100, which are enriched in basic amino acid residues, have been considered to be major LDLr-binding loci [2]. LDL is extremely susceptible to oxidation (ox) to the more atherogenic ox-LDL, which is not recognized by LDLr, but is taken up by scavenger receptors, such as SR-A1 and CD36 [1]. 
Spontaneous models of atherosclerosis have emerged through the introduction of genetic mutations in mice. Although the LDLr deficient $\left(\mathrm{Ldlr}^{-/-}\right)$mice and the mice exhibiting deficiency in apoE $\left(\mathrm{Apoe}^{-/-}\right)$are heavily used for these studies, $\mathrm{Apoe}^{-/-}$and $\mathrm{Ldlr^{-/- }}$ mice that are on a normal chow diet do not mimic type Ila hypercholesteroremia [3-5]. Murine hepatocytes express Apolipoprotein B Editing Enzyme 1 (Apobec1) that alters cytosine in the first base of codon 2153 of Apob mRNA to uracil. Therefore, codon 2153 is changed to "UAA" from "CAA", and murine liver secretes truncated apoB48 (2152 amino acids) containing VLDL. Its expression level increases after birth. The livers of mature 2 monthold mice synthesize VLDL, containing $70 \%$ apoB48 and $30 \%$ apoB100 [6]. Therefore, LDL in $L d l r^{-/}$mice does not increase significantly, unlike in humans. LDLr is not heavily involved in the clearance of LDL in this mode. It has been shown that a mouse model of elevated LDL is one in which both the $L d l r$ and Apobec1 genes are deleted $\left(L^{-/-} / A^{-/-}\right)$. This is due to the fact that these mice lack the ability to convert apoB100 to apoB48 in the liver and are defective in LDL clearance [7]. These doubly deficient mice slowly and progressively present with severe spontaneous atherosclerosis on a normal chow diet. They also exhibit high levels of apoB100-LDL-containing hypercholesterolemia, and more closely mirror the plasma lipid profiles in human atherosclerosis [8].

Plasminogen (Pg), which is encoded by the PLG gene in humans, is the zymogen of the serine protease, plasmin $(\mathrm{hPm})$. Human Pg is a $92 \mathrm{kDa}$ single chain glycoprotein that is activated by Pg activators (PA), e.g., tissue-type plasminogen activator (tPA) and urokinase-type plasminogen activator (uPA) [9], via the cleavage of a single peptide bond at $\mathrm{Arg}^{561}-\mathrm{Val}^{562}$, leading to the disulfide-linked, two-chain $\mathrm{hPm}$. The 561 amino acid Nterminal heavy chain contains five kringle domains, four of which bind to Lys-residues in fibrin [10], and other proteins, e.g., Pg receptors, in prokaryotes [11] and eukaryotes [12,13]. The potential importance of the fibrinolytic system in regulating atherosclerosis is highlighted by the observations of fibrin and fibrin degradation products in atherosclerotic plaques [14]. Mice with alteration in the gene-encoding components of the fibrinolytic system are powerful tools to evaluate the relationships between atherosclerosis and fibrin clearance. One study employing such mice indicated that Pg deficiency greatly accelerated the development of atherosclerotic lesions in $A p o e^{-/-}$mice without altering total cholesterol (TC) levels. The authors showed that Pg deficiency did not block the progression of lesions to any specific stage because mice of both genotypes carried intimal lesions. These had the qualitative appearance of early, intermediate, and advanced disease. The lesions included fibrous plaques containing necrotic cores, cholesterol clefts, macrophage foam cells, smooth muscle cells, and deposits of elastic fibers and collagen [15]. On the other hand, proteolytic cleavage of apoB100 by trypsin or plasmin $(\mathrm{Pm})$, in conjunction with hydrolysis of cholesteryl esters, generated lipoprotein particles that were similar to lesions derived from human LDL in structure, biological properties, and composition [16,17]. Further, Pm modified human LDLs were efficiently taken up by human macrophages [18,19]. Based on these results, we hypothesized that Pg binds to the Lys-rich C-terminus of apoB100, and Pm-mediated apoB100-modified LDL particles are efficiently taken up by macrophages. This reaction is significantly reduced by the presence of Apobec1 in Apoe ${ }^{-/-}$mice. We have generated $\mathrm{L}^{-1-} / \mathrm{A}^{-/-} / \mathrm{Plg}^{-/-}$mice and characterized the progression of plaque formation in these mice in order to test this hypothesis.

\section{Materials and Methods}

\subsection{Mice}

Plasminogen deficient mice $\left(\mathrm{Plg}^{-/-}\right)$and $\mathrm{L}^{-/-} / \mathrm{A}^{-/-}$mice were back-crossed into the C57Bl/6J strain (Jackson Laboratory, Bar Harbor, ME, USA) for at least seven generations before cross-breeding $[7,8,20-22]$. Triple heterozygous $\left(\mathrm{L}^{+/-} / \mathrm{A}^{+/-} / \mathrm{Plg}^{+-}\right)$mice were crossed to $L^{-/-} / A^{-/-}$to produce the $L^{-/-} / A^{-/-} / \mathrm{Plg}^{+/-}$as breeders. The primers and probes used for genotyping are listed in Supplementary Table S1. Male mice were used in in vivo experiments and both genders were used in in vitro experiments. Mice were maintained on a standard chow diet for 12-24 wk. Mice were fasted for at least $6 \mathrm{~h}$ and sacrificed at 
each time point using Isoflurane (Abbvie, North Chicago, IL, USA). The blood obtained was anticoagulated with sodium citrate, EDTA, or heparin. The hearts and whole aortic trees were removed for morphometrical analyses after perfusion with isotonic saline.

\subsection{Complete Blood Count (CBC) and Plasma Lipid Analysis}

Total white blood cell, platelet, monocyte, lymphocyte, and neutrophil counts were performed on EDTA-treated blood from all genotypes at $12 \mathrm{wk}$, using a Hemavet 950F5 (Drew Scientific Inc., Waterbury, CT, USA). Plasma was separated from whole citrated blood and utilized to measure TC using Cholesterol CII (Wako Chemicals, Richmond, VA, USA), and TG using GPO-TRINDER (MilliporeSigma, St. Louis, MO, USA) [8,23].

\subsection{FPLC Analysis for Cholesterol Fractions}

Cholesterol profiles were examined using $100 \mu \mathrm{L}$ of plasma with fast performance liquid chromatography (FPLC) on a Superose 6 HR (Amersham Pharmacia biotech, Piscataway, NJ, USA), as previously reported [8,23].

\subsection{Heart Sections}

Hearts were cut at the level of the lower edge of the atrium. The upper part, containing the aortic valve, was fixed with periodate-lysine-paraformaldehyde (PLP) for $16 \mathrm{~h}$ at $4{ }^{\circ} \mathrm{C}$. After fixation, some samples were directly embedded in Tissue-Tec OCT (Sakura Fine Tec Co., Torrance, CA, USA). Other samples were processed and embedded in paraffin, cut side down. Thirty serial sections (from \#1 to \#30) were obtained at $4 \mu \mathrm{m}$ thickness from the aortic valve toward the ascending aorta, as previously described [8,23].

\subsection{Histochemistry and Immunohistochemistry}

Serial sections were used for hematoxylin II and eosin Y (H\&E) (Richard Allen Scientific, Kalamazoo, MI, USA). The sections were also stained in oil red O (ORO; Sigma-Aldrich, St. Louis, MO, USA) and Masson's trichrome in order to detect lipid accumulation in the plaque for the determination of the size of the plaque in the aortic bulb, as previously described [8,23]. Immunohistochemical staining of macrophages was performed with rat-anti-mouse MAC3 and F4/80 cocktail (BD Pharmingen and AbD Serotec MorphoSys US, Raleigh, NC, USA, respectively). The stained slides were digitally scanned at $20 \times$ magnification with an Aperio CS digital slide scanner (Aperio Technologies, Vista, CA, USA).

\subsection{Assessment of Hepatic VLDL-TG Production}

After a $6 \mathrm{~h}$ fasting period, mice were anesthetized by i.p. administration of $0.075 \mathrm{mg} / \mathrm{g}$ ketamine $/ 0.015 \mathrm{mg} / \mathrm{g}$ xylazine $/ 0.0025 \mathrm{mg} / \mathrm{g}$ aceprozamine. In order to block TG hydrolysis and hepatic lipoprotein uptake, $500 \mu \mathrm{g} / \mathrm{g}$ of Tyloxapol (Triton WR-1339; Fisher Scientific, Hampton, NH, USA) was injected via the tail vein [24]. Blood samples $(30 \mu \mathrm{L})$ were withdrawn at $0,30,60,90$, and 120 min after injection, and plasma TG levels were measured, as described above. The VLDL-TG production rates were then calculated.

\subsection{Culture of Bone Marrow-Derived Macrophages}

Bone marrow was collected from the femurs of $L^{-/-} / A^{-/-}$and $L^{-1-} / A^{-/-} / \mathrm{Plg}^{-/-}$ mice at 8-12 wk. Bone marrow-derived macrophages were generated. This was performed by culturing non-adherent bone marrow cells with RPMI 1640 medium (MilliporeSigma), supplemented with $20 \%$ FCS $/ 30 \%$ L-cell conditioned medium (as the source of M-CSF)/antibiotic/antimycotic solution (100 U/mL of penicillin G, $100 \mu \mathrm{g} / \mathrm{mL}$ of streptomycin, and $250 \mathrm{ng} / \mathrm{mL}$ of amphotericin B; Sigma-Aldrich) for 7 days. Most cells were adherent to the dishes, and floating cells were removed by washing twice with warm HBSS (Millipore Sigma). The adherent bone marrow-derived macrophages were incubated with ice cold sterile HBSS for $15 \mathrm{~min}$ at $4^{\circ} \mathrm{C}$ to detach, and the cells were then collected. 


\subsection{DiI-Oxldl Uptake by Bone Marrow-Derived Macrophages}

The collected bone marrow-derived macrophages as above were resuspended in the conditioned media at $5.0 \times 10^{6}$ cells $/ \mathrm{mL}$. The $100 \mu \mathrm{L}$ cell suspension $\left(5.0 \times 10^{5}\right.$ cells $)$ was placed into each well of a 96-well plate, and the cells were incubated at $37^{\circ} \mathrm{C}$ in a $5 \% \mathrm{CO}_{2}$ incubator for $16 \mathrm{~h}$ to settle. The media were removed, and the cells were washed twice with warm HBSS. The cells were incubated with $100 \mu \mathrm{L}$ RPMI1640 containing DiI-oxLDL ( $20 \mu \mathrm{g} / \mathrm{mL}$; Biomedical Technologies) at $37^{\circ} \mathrm{C}$ in a $5 \% \mathrm{CO}_{2}$ incubator for $5 \mathrm{~h}$. The DiI was subsequently extracted from the cells using $100 \mu \mathrm{L}$ of 2-propanol. The fluorescent intensity was measured using an ABI prism 7700 (Applied Biosystems, Foster City, CA, USA) using the Joe channel (absorption at $520 \mathrm{~nm}$ and emission at $548 \mathrm{~nm}$ ). Various concentrations of murine wild-type (wt) Pg and an active site mutant $\left[\mathrm{S}^{743} \mathrm{~A}\right]-\mathrm{Pg}$ recombinantly synthesized by $\mathrm{S} 2$ cells, which are derived from Drosophila melanogaster, without bovine serum [25], along with aprotinin (USB Corporation, Cleveland, $\mathrm{OH}, \mathrm{USA}$ ), were added to the culture to evaluate the functions of Pg and Pm. We have chosen Drosophila S2 cells without fetal bovine serum, as opposed to mammalian cell lines, to express recombinant Pg because of the ubiquitous presence of $\mathrm{hPg}$ activators in mammalian cells.

\subsection{RNA Sequencing}

Total RNA was extracted from the livers of the $\mathrm{L}^{-/-} / \mathrm{A}^{-/-}$and $\mathrm{L}^{-/-} / \mathrm{A}^{-/-} / \mathrm{Plg}^{-/-}$ mice using the RNeasy Mini Kit (Qiagen, Valencia, CA, USA). The total RNA quality was evaluated using a NanoDrop 1000 (Thermo Fisher Scientific, Waltham, MA, USA), and the RNA integrity of the samples was assessed. All samples passed the quality checks. Libraries were constructed using a TruSeq Stranded mRNA LT Sample Prep Kit (Illumina, San Diego, CA, USA) and sequenced on the Illumina platform. Raw data was trimmed using Trimmomatic 0.38 (www.usadellab.org/cms/?page=trimmomatic (accessed on 19 March 2020)). Trimmed data was mapped to a reference genome (mm10) using HISAT2 v. 2.1.0 and Bowtie2 v. 2.3.4.1 (ccb.jhu.edu/software/hisat2/index.shtml (accessed on 19 March 2020)). Differentially expressed genes (DEGs) were identified using StringTie v. 2.1.3b (ccb.jhu.edu/software/stringtie/ (accessed on 19 March 2020)). The significance threshold was $p<0.05$. The fold change was $>2$ or $<0.5$ and this was used to identify DEGs. Gene Ontology (GO) enrichment analysis and Kyoto Encyclopedia of Genes and Genomes (KEGG) pathway enrichment analysis of the DEGs were conducted. These processes were supported by Macrogen Japan Corp (Tokyo, Japan).

\subsection{Fluorescence-Assisted Cell Sorting (FACS) of Macrophages in Lever}

FACS was performed as described in [26]. The mice were briefly perfused with EGTA (ethylene glycol tetra-acetic acid)/HBSS (Hank's balanced salt solution)/collagenase (Sigma-Aldrich). After filtration through a cell strainer, the cells were collected using percoll. The resulting samples were stained with antibodies against CD45, CD11b, and F4/80 and sorted using a MoFlo Astrios (Beckman Coulter, Brea, CA, USA) for mRNA expression analysis.

\subsection{Quantitative Real-Time PCR}

Total RNA was extracted as above from livers and hepatocytes, as well as the sorted cells. Reverse transcription was performed using a ReverTra Ace qPCR RT Master Mix with gDNA Remover (TOYOBO, Tokyo, Japan). Quantitative, real-time PCR was performed using the THUNDERBIRD SYBR qPCR Mix (TOYOBO) and QuantStudio 3 (Thermo Fisher Scientific). The CD36 primer sequences were $5^{\prime}$-CAAAACGACTGCAGGTCAAC- $3^{\prime}$ (forward) and $5^{\prime}$-CCAATGGTCCCAGTCTCATT-3' (reverse). The $18 \mathrm{~S}$ rRNA primer sequences were 5'-GGTAACCCGTTGAACCCCAT-3' (forward) and 5'-CAACGCAAGCTTATGACCCG-3' (reverse). The results were expressed as the mRNA level relative to $18 \mathrm{~S}$ rRNA mRNA as an internal control. 


\subsection{Statistical Analyses}

The data are presented as the mean \pm SD. The size of plaques and plasma levels of Total-C, VLDL-C, LDL-C, and HDL-C, triglyceride, de novo hepatic synthesis of VLDL, sP-Sel and sE-sel, and mRNA levels were analyzed using Student's t-test for each time point. The DiI-oxLDL uptakes were analyzed using one-way factorial ANOVA, followed by Scheffe. All analyses were performed using the R Statistical Computing Package ( $\mathrm{R}$ Developmental Core Team, http:/ / www.R-project.org (accessed on 14 May 2020)), and null hypothesis was declined at $p<0.05$.

\section{Results}

\subsection{Plaque Progression in Whole Aorta and Aortic Sinus}

The plaque covered area in whole aorta (Figure 1 ) and the plaque size in aortic sinuses (Figure 2) were analyzed. The area and the size were increased from 12, 18, and $24 \mathrm{wk}$ of age in $L^{-/-} / A^{-/-}$mice (Figures 1 and 2). The plaques were only visible in the aortic arches of mice at $12 \mathrm{wk}$ of age, and were conspicuous around the intercostal and celiac arteries at $24 \mathrm{wk}$ of age (Figure 1a). This increase continued through $72 \mathrm{wk}$ of age in $\mathrm{L}^{-/-} / \mathrm{A}^{-/-}$ mice [8]. On the other hand, those in $\mathrm{L}^{-1-} / \mathrm{A}^{-/-} / \mathrm{Plg}^{-/}$mice were more significantly reduced at 12,18, and $24 \mathrm{wk}$ of age than the plaques in $L^{-/-} / A^{-/-}$mice (Figures 1 and 2). These results indicated that the rate of progression of plaques was restricted, and the initiation of plaque formation was delayed.
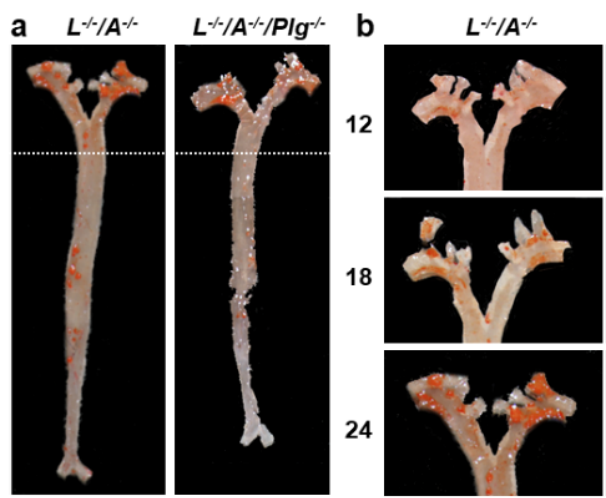

$L^{-\% / A} \% / P I g /$

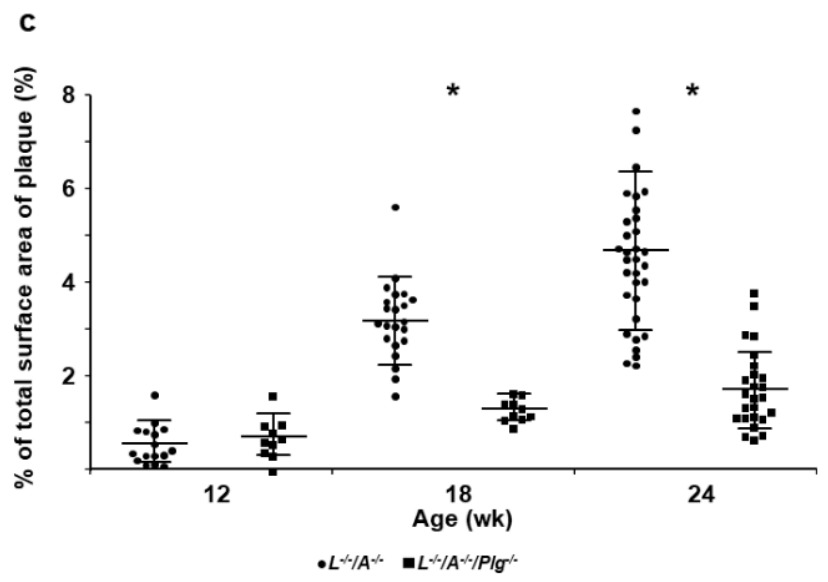

Figure 1. Plaque formation in entire aortic trees. (a) Sudan IV staining of whole aortic trees in $\mathrm{L}^{-/-} / \mathrm{A}^{-/-}$and $\mathrm{L}^{-/-} / \mathrm{A}^{-/-} / \mathrm{Plg}^{-/-}$mice at $24 \mathrm{wk}$ of age. (b) Sudan IV staining of whole aortic arches in $L^{-/-} / A^{-/-}$and $L^{-/-} / A^{-/-} / \mathrm{Plg}^{-/-}$mice at 12,18 , and $24 \mathrm{wk}$ of age. (c) The percentage of total surface occupied by plaque in the aorta of $L^{-/-} / A^{-/-}$mice was $0.56 \pm 0.41,3.1 \pm 0.91$, and $4.6 \pm 1.7$ at 12,18 , and $24 \mathrm{wk}$ of age, respectively (circles). That in $\mathrm{L}^{-/-} / \mathrm{A}^{-/-} / \mathrm{Plg}^{-/-}$mice was $0.69 \pm 0.44$, $1.3 \pm 0.24$, and $1.7 \pm 0.84$ at $12-, 18-$, and 24 wk of age, respectively (squares), $(n=10-58){ }^{*} p<0.05$. 

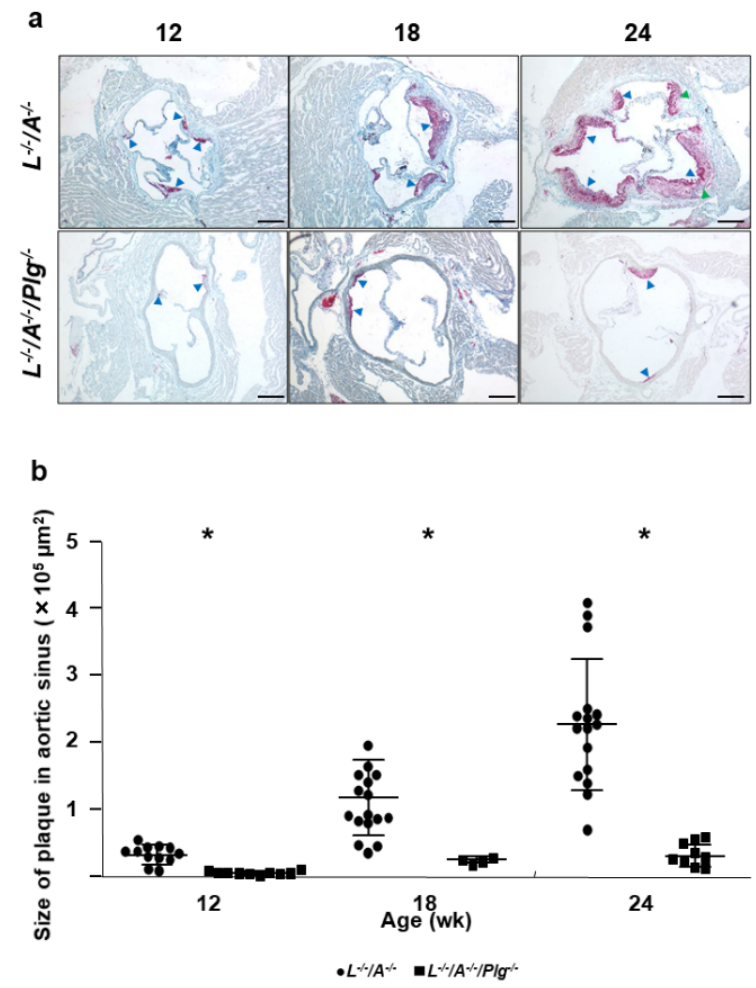

Figure 2. (a) Oil red $\mathrm{O}(\mathrm{ORO})$ stains for lipids associated with the aortic sinuses from $L^{-/-} / A^{-/-}$and $\mathrm{L}^{-/-} / \mathrm{A}^{-/-} / \mathrm{Plg}^{-/-}$male mice at various ages. In $12 \mathrm{wk} \mathrm{L}^{-/-} / \mathrm{A}^{-/-}$mice, there were dense droplets of lipids associated with the base of aortic valves (blue arrowheads). In $12 \mathrm{wk} \mathrm{L}^{-/-} / \mathrm{A}^{-/-} / \mathrm{Plg}^{-/-}$ mice, the area of fat accumulation was smaller than in $L^{-/-} / A^{-/-}$(blue arrowheads). In $18 \mathrm{wk}$ $L^{-/-} / A^{-/-}$mice, the neointima was clearly observed with dense fat accumulation (blue arrowheads). In $18 \mathrm{wk} \mathrm{L}^{-/-} / \mathrm{A}^{-/-} / \mathrm{Plg}^{-/-}$mice, the area of fat accumulation was enhanced relative to $12 \mathrm{wk}$ mice although neointima formation was significantly restricted compared with $L^{-/-} / A^{-/-}$at the same age (blue arrowheads). In $24 \mathrm{wk} L^{-/-} / A^{-/-}$mice, the neointima was enhanced (blue arrowheads). The lipid stains in the neointima became less dense particularly in the core due to the formation of complex plaque (green arrowheads). In $24 \mathrm{wk} \mathrm{L}^{-/-} / \mathrm{A}^{-/-} / \mathrm{Plg}^{-/-}$mice, small and restricted neointima formation was observed (blue arrowheads). Original magnification, $40 \times$. Bar $=250 \mu \mathrm{m}$. (b) Plaque sizes in aortic sinuses of $L^{-/-} / A^{-/-}$were $0.33 \pm 0.15,1.2 \pm 0.57$, and $2.3 \pm 0.93$ at 12,18 , and $24 \mathrm{wk}$ of age, respectively (circles). Those in $L^{-/-} / A^{-/-} / \mathrm{Plg}^{-/-}$mice was $0.046 \pm 0.026,0.23 \pm 0.045$, and $0.31 \pm 0.17$ at 12,18 , and $24 \mathrm{wk}$ of age, respectively. Those in $\mathrm{L}^{-/-} / \mathrm{A}^{-/-} / \mathrm{Plg}^{-/-}$(squares) mice, as revealed by morphometric analysis of ORO-stained slides $(n=4-16) .{ }^{*} p<0.05$.

\subsection{Histological and Immunohistological Characterization of Plaques}

H\&E stains from 18 wk old mice demonstrated that $L^{-/-} / A^{-/-}$mice partially developed a fibrous cap on the surface of plaque. Notwithstanding, $L^{-/-} / A^{-/-} / \mathrm{Plg}^{-/-}$ mice contained very small plaques at this stage. ORO stains demonstrated that both sets of mice contained lipid-accumulated plaques; although, the sizes of the plaques in $L^{-/-} / A^{-/-} / \mathrm{Plg}^{-/-}$mice were much smaller than those in $L^{-/-} / A^{-/-} / \mathrm{Plg}^{-/-}$mice. Trichrome stains revealed a collagen core associated with SMCs in $L^{-/-} / A^{-/-}$mice. In contrast, neither collagen deposits nor SMCs were found in plaques of $\mathrm{L}^{-/-} / \mathrm{A}^{-/-} / \mathrm{Plg}^{-/-}$mice. Macrophage immunostains were positive in plaques in both genotypes. However, the positive stains in plaques of $L^{-/-} / A^{-/-}$mice were rarely associated with nuclei, in contrast to the positive stains associated with nuclei in plaques in $\mathrm{L}^{-/-} / \mathrm{A}^{-/-} / \mathrm{Plg}^{-/-}$mice (Figure 3 ). These results indicated that the reduced progression of plaques in $L^{-/-} / A^{-/-} / \mathrm{Plg}^{-/-}$mice was correlated to the foam cell formation of macrophages. 

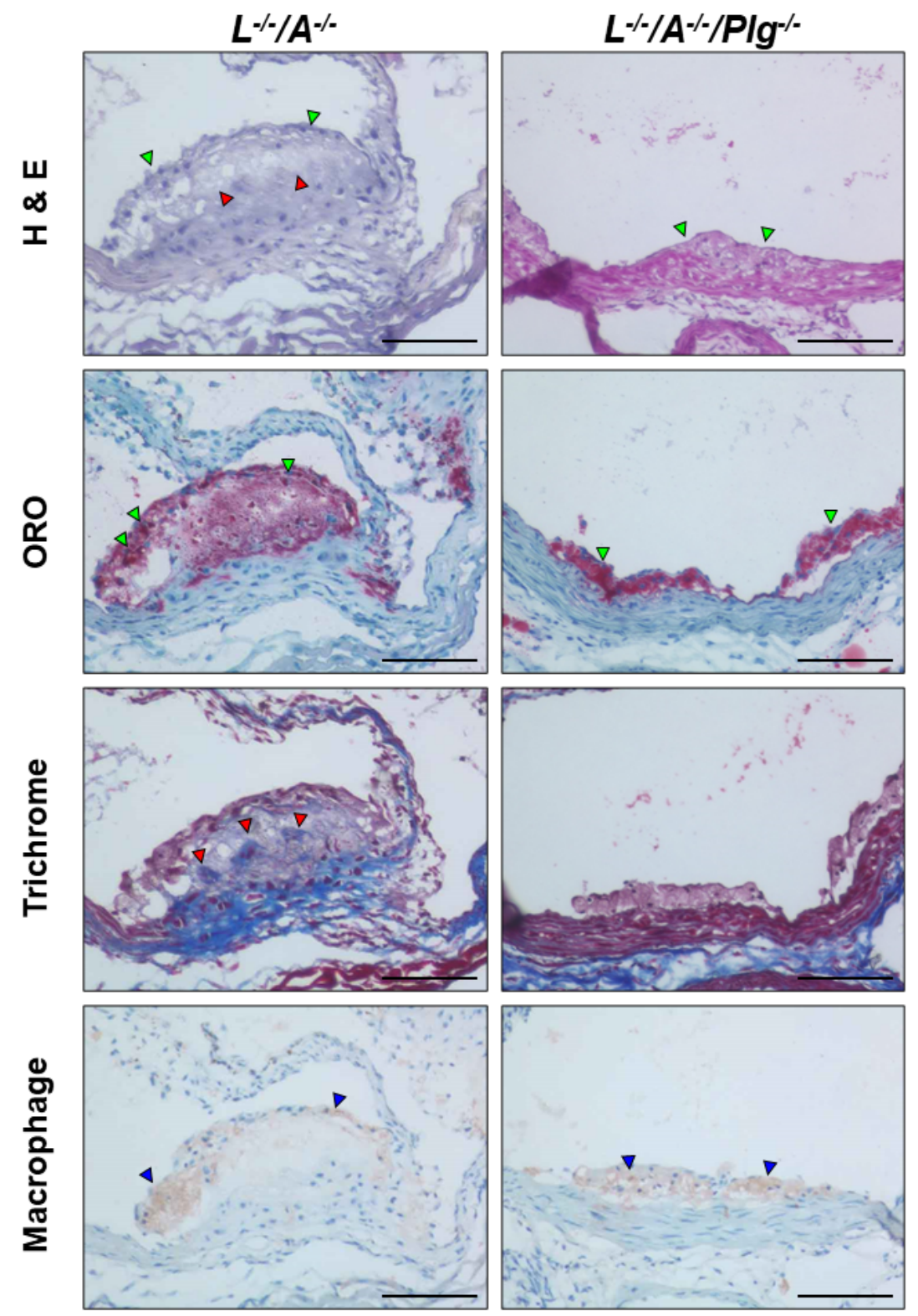

Figure 3. Stained plaque from $L^{-/-} / A^{-/-}$and $L^{-/-} / A^{-/-} / P l g^{-/-}$male mice at $18 \mathrm{wk}$ of age. H\&E stains in $L^{-/} / A^{-/-}$demonstrated cellular cap formation on the surface of the plaque (green arrowheads) with acellular areas (red arrowheads). H\&E stains in $L^{-/-} / A^{-/-} / \mathrm{Plg}^{-/-}$mice indicated that the size of plaque was very small and only a few cell layers were observed (green arrowheads). ORO stains in $L^{-/-} / A^{-/-}$mice demonstrated that the dense fat accumulation was mainly localized on the surface of the plaque (green arrowheads). Fat accumulation was diffuse in the core. ORO stains in $L^{-/-} / A^{-/-} / \mathrm{Plg}^{-/-}$mice demonstrated small but very dense fat accumulation in the plaque (green arrowheads), which was found earlier in $L^{-/-} / A^{-/-}$mice. Masson's trichrome stains in $L^{-/-} / A^{-/-}$ mice showed diffuse and patchy collagen deposition (red arrowheads). Masson's trichrome stains in $L^{-/-} / A^{-/-} / \mathrm{Plg}^{-/-}$mice indicated an absence of collagen deposition in the plaque. Macrophage immunostains in $L^{-/} / A^{-/-}$mice showed positive stains mainly localized in the cap area (blue arrowheads). Macrophage immunostains in $L^{-/-} / A^{-1-} / \mathrm{Plg}^{-/-}$mice indicated that almost all of the cells were positive in the small cap (blue arrowheads). Original magnification, $200 \times$. Bar $=100 \mu \mathrm{m}$.

\subsection{Lipid Analysis and De Novo Hepatic Synthesis of VLDL}

The values of TC, TG, VLDL-C, LDL-C, HDL-C, and LDL-C/HDL-C are summarized in Figure 4. The plasma levels of TC, VLDL-C, LDL-C, and LDL-C/HDL-C in $\mathrm{L}^{-/-} / \mathrm{A}^{-/-} / \mathrm{Plg}^{-/-}$ mice were significantly higher than those in $L^{-/-} / A^{-/-}$mice (Figure $4 \mathrm{a}-\mathrm{d}, \mathrm{f}$, respectively). The 
plasma levels of TG in $\mathrm{L}^{-/-} / \mathrm{A}^{-/-} / \mathrm{Plg}^{-/-}$mice were significantly lower than those in $L^{-/-} / A^{-/-}$mice (Figure $4 \mathrm{~b}$ ). However, there were no significant differences in HDL-C levels (Figure 4e). In contrast, $A \mathrm{poe}^{-/-} / \mathrm{Plg}^{-/-}$mice showed down-regulated HDL-C without changing TC [15]. TG levels in both $\mathrm{L}^{-/-} / \mathrm{A}^{-/-} / \mathrm{Plg}^{-/-}$and $\mathrm{Apoe^{-/- }} / \mathrm{Plg}^{-/-}$mice were diminished. Since $\mathrm{Plg}^{-/-}$mice showed recto-prolapse and the body weight was decreased after developing it, we have speculated that the TG levels reflected to the food intake. De novo hepatic synthesis of VLDL-TG was more significantly reduced in $\mathrm{L}^{-/-} / \mathrm{A}^{-/-} / \mathrm{Plg}^{-/-}$ mice than in $L^{-/-} / A^{-/-}$mice (Figure $4 \mathrm{~g}$, $\mathrm{h}$ ); thus, clearly indicating that up-regulation of LDL-C was not initiated by over synthesis of VLDL.
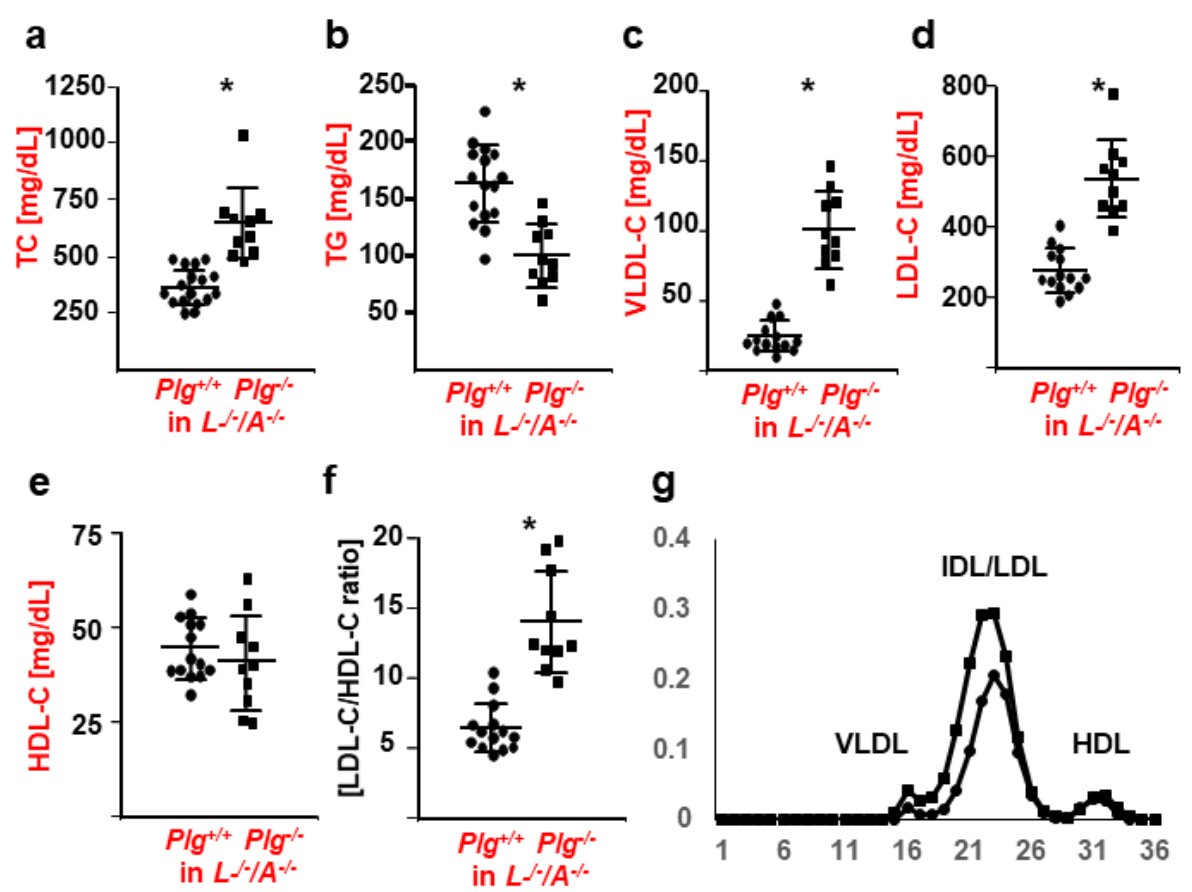

h
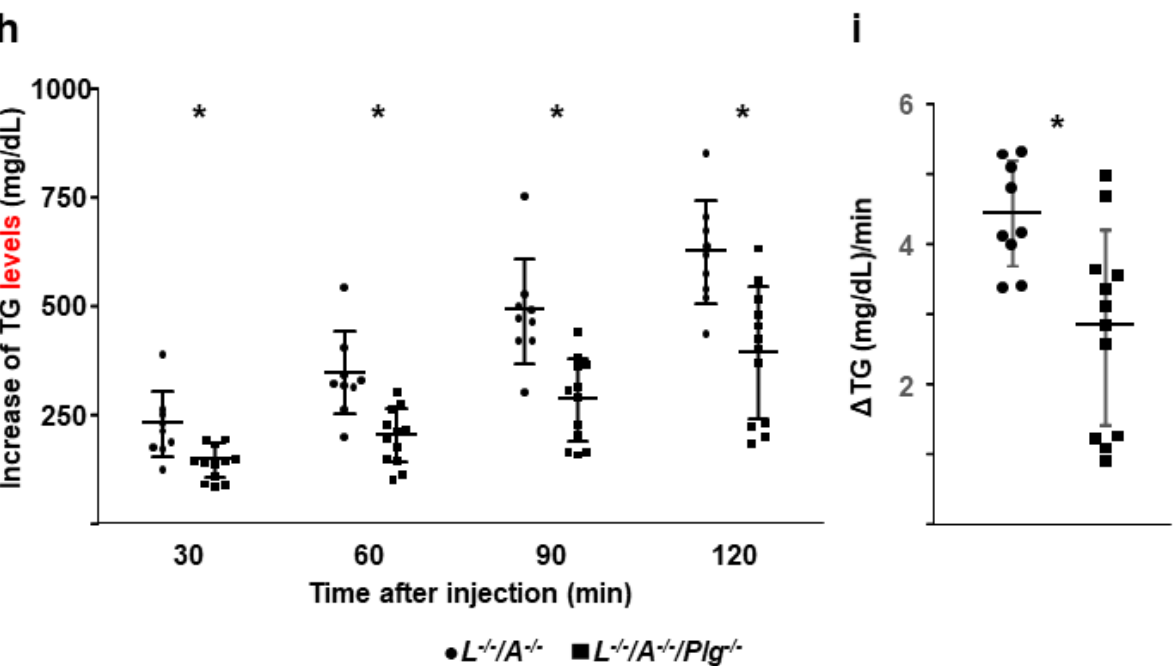

Figure 4. Lipid profiles, CBC, and De novo hepatic synthesis of VLDL. (a) TC, (b) TG, (c) VLDL-C, (d) LDL-C, (e) HDL-C, and (f) LDL-C/HDL-C in $\mathrm{L}^{-/-} / \mathrm{A}^{-/-}$(circles) and $\mathrm{L}^{-/-} / \mathrm{A}^{-/-} / \mathrm{Plg}^{-/-}$(squares) mice $(n=8-19)$. (g) Typical FPLC profile. (h) Increase in plasma TG as de novo VLDL synthesis in $L^{-/-} / A^{-/-}$(circles) and $L^{-/-} / A^{-/-} / \mathrm{Plg}^{-/-}$(squares) mice $(n=9-12)$. (i) The VLDL production rate was calculated. ${ }^{*} p<0.05$. 


\subsection{OxLDL Uptake by Macrophages Is Diminished with a Pg Deficiency}

After it was determined that there were differences in the oxidation status of plasma between the two mouse genotypes, an analysis of the efficiency of uptake of oxLDL by macrophages was carried out. Bone marrow-derived macrophages from $L^{-1-} / A^{-1-}$ mice were incubated with increasing concentrations of $\mathrm{Pg}$ in the presence and absence of the $\mathrm{hPm}$ inhibitor, aprotinin. Dil-labeled human oxLDL uptake increased with the addition of $\mathrm{Pg}$ in a dose-dependent manner and uptake was virtually abolished with the addition of aprotinin, or through the use of a recombinant Pg-active site mutant (PgS743A) (Figure 5a). The in vitro uptake of LDL by macrophages from $\mathrm{L}^{-/-} / \mathrm{A}^{-/-}$and $\mathrm{L}^{-/-} / \mathrm{A}^{-/-} / \mathrm{Plg}^{-/-}$was assessed by FPLC of LDL, isolated from $\mathrm{L}^{-/} / \mathrm{A}^{-/-}$and $\mathrm{L}^{-1-} / \mathrm{A}^{-/-} / \mathrm{Plg}^{-/-}$mice. Uptake of LDL was the least efficient in bone marrow-derived macrophages and LDL from $\mathrm{L}^{-/-} / \mathrm{A}^{-/-} / \mathrm{Plg}^{-/-}$mice (Figure $5 \mathrm{~b}$ ). These results indicated that Pm-mediated LDL was more atherogenic and the uptake of oxLDL by macrophages was dependent Pm.

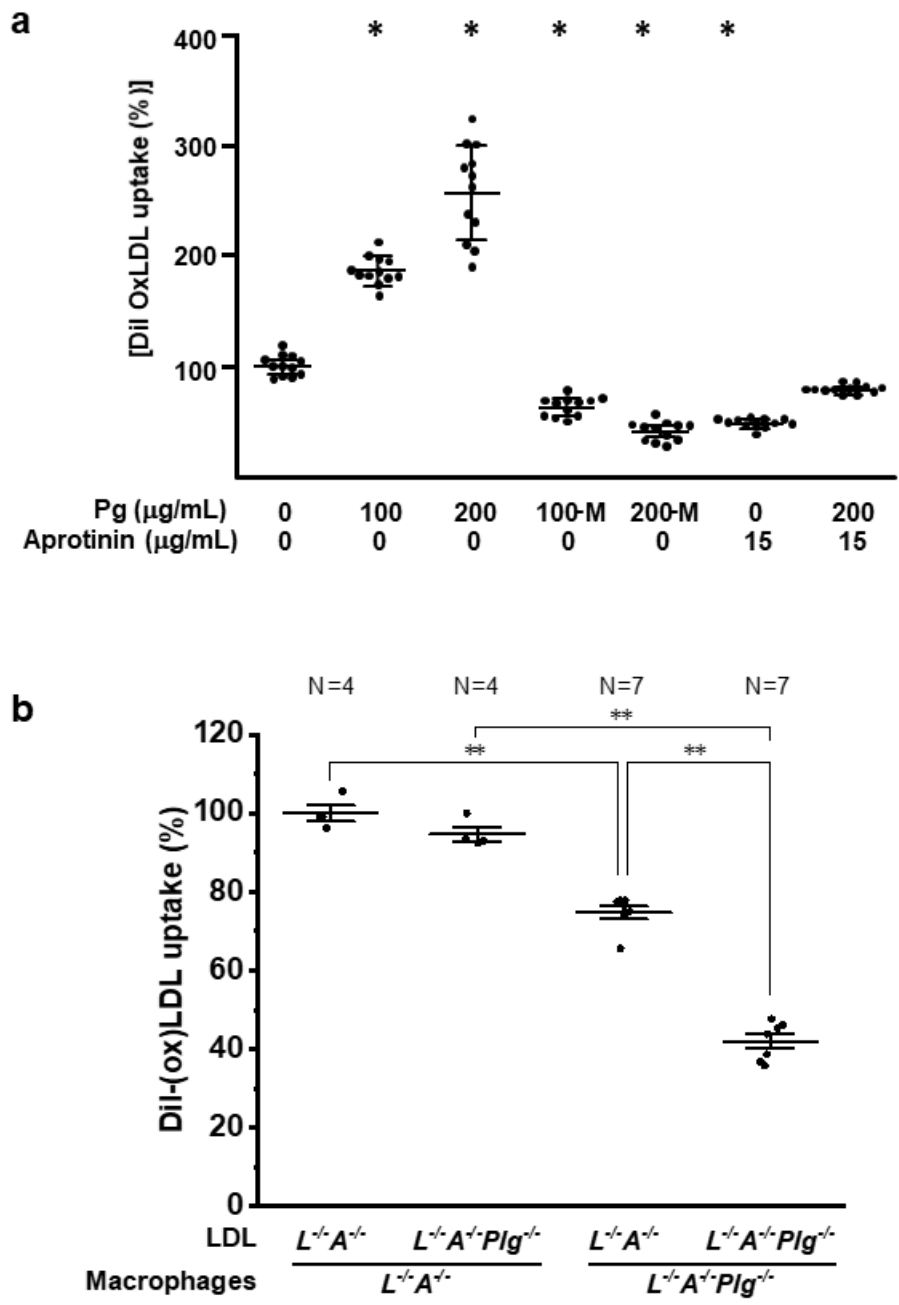

Figure 5. LDL/oxLDL uptake. (a) Purified and Dil-labeled oxLDL was incubated with bone marrowderived macrophages from $12 \mathrm{wk} L^{-/-} / A^{-/-}$mice $(n=12)$, in the absence or presence of increasing concentrations of $\mathrm{Pg}$ and in the absence or presence of the plasmin inhibitor, aprotinin. $\mathrm{M}$-active site mutant Pg protein (PgS743A). ${ }^{*} p<0.05$ versus (-) $\mathrm{mPg}$ and (-) aprotinin. (b) LDL was isolated from $L^{-/-} / A^{-/-}$and $L^{-/-} / A^{-/-} / \mathrm{Plg}^{-/-}$mice, Dil-labeled, and then incubated with bone marrowderived macrophages from $L^{-/-} / A^{-/-}$(circles) or $L^{-/-} / A^{-/-} / \mathrm{Plg}^{-/-}$(squares) mice at $12 \mathrm{wk}$ of age. Macrophages isolated from $12 \mathrm{wk}$ mice and LDL obtained from $12 \mathrm{wk}$ mice $(n=4$ for circles and $n=7$ for squares) $* p<0.05$. " $*$ " is “**” between the pairs of comparisons. 


\subsection{RNA Sequencing and the Expression of $C d 36$}

We conducted sequencing of RNA from the liver, since the liver plays a key role in lipid metabolism. In total, 753 differentially expressed genes (DEGs) were identified using the specified selection criteria $(p<0.05$; fold change $>2$ or $<0.5)$. Of these, expression levels of 337 were upregulated while those of 416 were downregulated in $\mathrm{L}^{-/-} / \mathrm{A}^{-/-} / \mathrm{Plg}^{-/-}$mice compared with $L^{-/} / A^{-1-}$ mice. After checking the profiles by comparing expression of scavenger receptors and genes related to lipid metabolisms, it was clearly confirmed that $C d 36$ expression in liver was lower in $\mathrm{L}^{-/-} / \mathrm{A}^{-/-} / \mathrm{Plg}^{-/-}$mice than in $\mathrm{L}^{-/-} / \mathrm{A}^{-/-}$ mice (Figure 6a). To validate these RNA sequencing results, we performed q-RTPCR on 40 liver samples, including the RNA sequencing on 6 samples. These PCR results revealed lower $C d 36$ expression in $L^{-/-} / A^{-/-} / \mathrm{Plg}^{-/-}$mice than in $\mathrm{L}^{-/-} / \mathrm{A}^{-/-}$(Figure $6 \mathrm{~b}$ ). Then, macrophages were sorted from livers in order to analyze the expression of $C d 36$ in macrophages (Figure 6c). Macrophages were subsequently sorted from livers in order to analyze the expression of $C d 36$ in macrophages (Figure 6c). A recently developed FACS protocol enabled distinction between resident and recruited macrophages [26]. As shown in Figure $6 \mathrm{~d}-\mathrm{f}$, the mRNA expression levels of $C d 36$ in hepatocytes showed that recruited and resident macrophages were all reduced in $\mathrm{L}^{-/-} / \mathrm{A}^{-/-} / \mathrm{Plg}^{-/-}$compared with $\mathrm{L}^{-/-} / \mathrm{A}^{-/-}$. Interestingly, the mRNA expression level of $C d 36$ in resident macrophages was significantly higher than that of liver, hepatocytes, and recruited macrophages (Figure 6g).

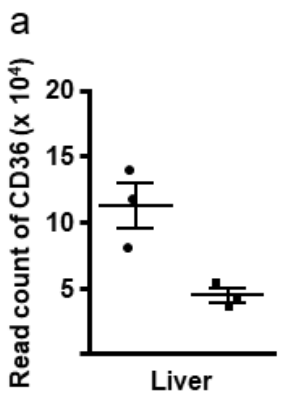

b
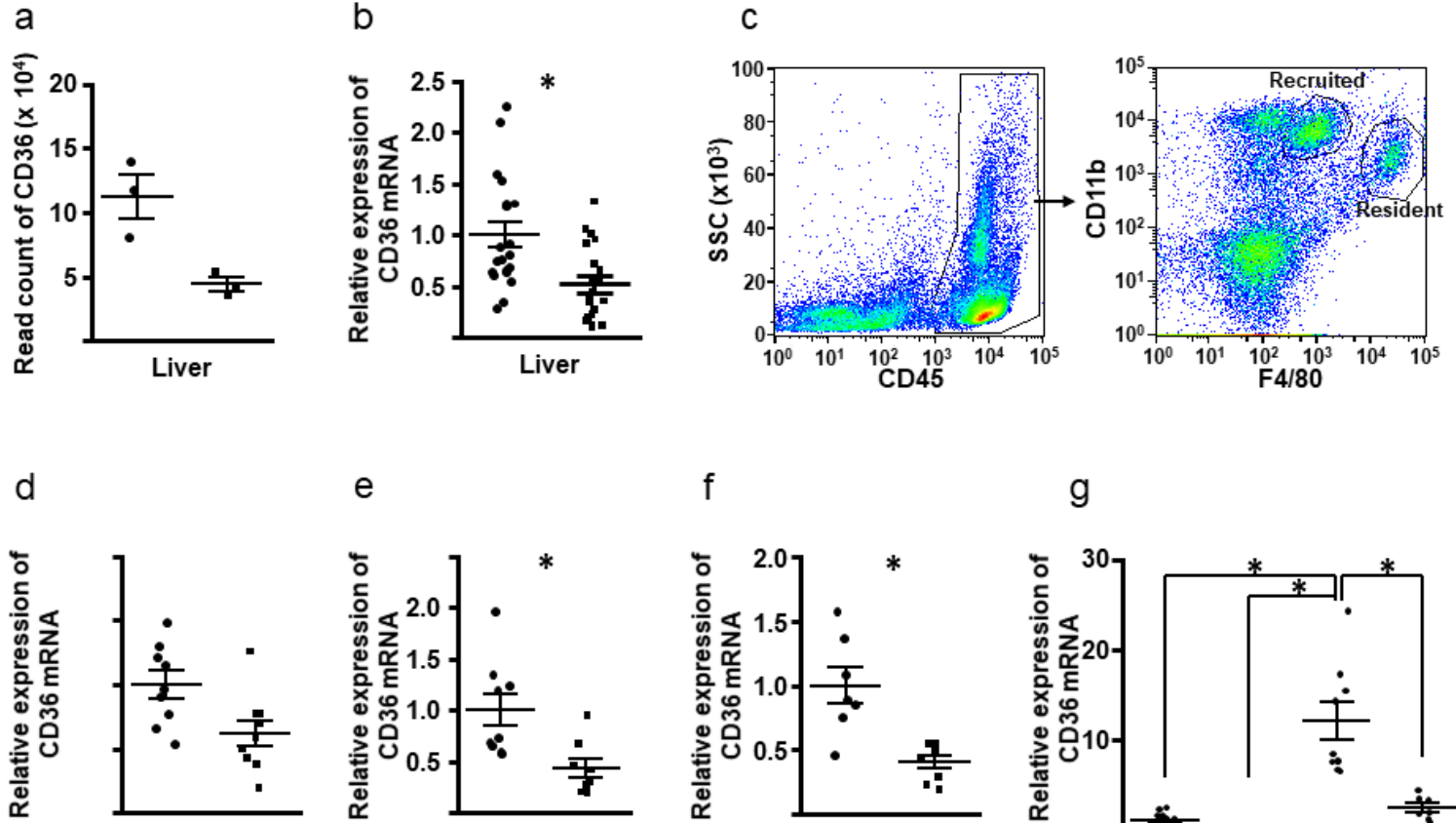

e

f

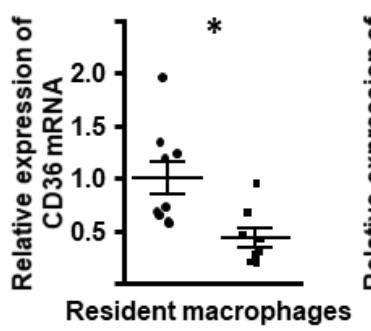

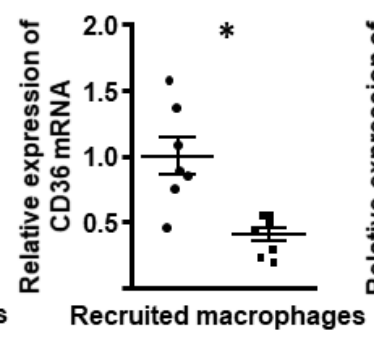

g

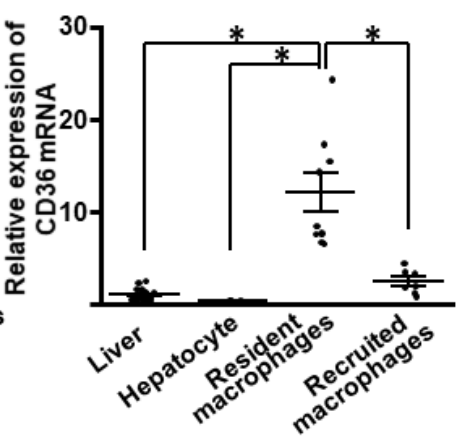

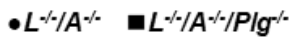

Figure 6. (a) Read count of $C d 36$ by RNA sequencing $(n=3)$. (b) The mRNA expression levels of $C d 36$ in liver $(n=20)$. (c) CD45+ cells were analyzed with F4/80 and CD11b, and resident (F4/80hi) and recruited (CD11bhi) macrophages were sorted. (d-f) The mRNA expression levels of $C d 36$ in hepatocytes and recruited and resident macrophages $(n=7-9)$. (g) Comparison of the mRNA expression levels of $C d 36$ in liver, hepatocytes, and recruited and resident macrophages in $L^{-/-} / A^{-/-}$mice $(n=7-20)$. ${ }^{*} p<0.05$ between $L^{-/-} / A^{-/-}$and $L^{-/-} / A^{-/-} / \mathrm{Plg}^{-/-}$in $(\mathbf{b}, \mathbf{e}, \mathbf{f})$. In $(\mathbf{g})$, between the pairs of comparisons. 


\section{Discussion}

It is a known medical fact that $A p o e^{-/-}$mice are characterized as a VLDL-C dominant spontaneous atherosclerosis model. On the other hand, $L^{-/-} / A^{-/-}$mice are characterized as an LDL-C dominant model [7,8]. Even though high levels of both VLDL-C and LDL-C could initiate and propagate atherosclerotic plaques, the processes involved in plaque formation by different types of hypercholesterolemia differ. Indeed, VLDL remnants could trigger foam cell formation from monocytes/macrophages via VLDLr-mediated uptake, without oxidization [27]. However, such oxidization is critical for LDL to initiate foam cell formation [28-30]. Furthermore, VLDL can bind to coagulation factors (F)II, FVII, FIX, and FX, which are Vitamin K-dependent proteins containing g-carboxyglutamate (Gla) domains that facilitate binding to phospholipids. On the other hand, binding of these proteins to LDL has not been documented [31]. Only one molecule of apoB100 is present in a particle of VLDL/IDL/LDL, but the surface of human LDL is almost completely covered by apoB100 [2]. Thus, there are few phospholipids on LDL available to bind these proteins. Additionally, the Lys-rich C-terminus of apoB100 in LDL is a potential target of Pg binding, followed by proteolytic degradation, and this reaction is reduced in mice due to the presence of Apobec1 in their livers. These considerations indicate that alterations in the coagulation and fibrinolytic systems, induced by hypercholesterolemia, may be dependent on the types and/or components of lipoproteins. Therefore, we developed the lipid profiles of $L^{-/} / A^{-/-} / \mathrm{Plg}^{-/-}$mice and analyzed them in the current study.

In this study, an additional $\mathrm{Pg}$ deficiency in $\mathrm{L}^{-/-} / A^{-/-}$mice upregulated plasma levels of TC, VLDL-C, and LDL-C, but did not affect HDL-C levels, and de novo VLDL synthesis was impaired in $\mathrm{L}^{-/-} / \mathrm{A}^{-/-} / \mathrm{Plg}^{-/-}$mice. Thus, upregulation of LDL-C was the result of reduced clearance of this lipid particle. Although hypercholesterolemia, especially in the LDL-C class, was observed in $\mathrm{L}^{-/-} / \mathrm{A}^{-/-} / \mathrm{Plg}^{-/-}$mice, the sizes of the plaques were dramatically reduced, and the progression of plaque development was retarded. These results were in contrast to those obtained with $\mathrm{Apoe}^{-/-} / \mathrm{Plg}^{-/-}$mice [15].

Monocyte infiltration to the plaques was enhanced in $\mathrm{Apoe}^{-/-} / \mathrm{Plg}^{-/-}$mice [15] and this phenomenon was also detected in $\mathrm{L}^{-/-} / \mathrm{A}^{-/-} / \mathrm{Plg}^{-/-}$mice. Moreover, monocyte recruitment into the liver of both $\mathrm{L}^{-/-} / \mathrm{A}^{-/-}$and $\mathrm{L}^{-/-} / \mathrm{A}^{-/-} / \mathrm{Plg}^{-/-}$mice was not different. It is well known that the vascular endothelial structure in $\mathrm{BM}$ and the liver is a perforated structure. The numbers of WBCs in the blood were highly elevated in $\mathrm{Plg}^{-/-}$mice [20] as well as in $\mathrm{L}^{-/-} / \mathrm{A}^{-/-} / \mathrm{Plg}^{-/-}$mice (data not shown). Taken together, the transfer of WBCs through a specific endothelium was demonstrated to be unaffected by Pg deficiency. This was probably because this pathway did not require the use of extracellular matrix proteolysis. Therefore, macrophage infiltration from damaged vascular endothelial cells of the aorta into the subendothelial cell layer may be unaffected by Pg deficiency.

In contrast, oxLDL uptake by macrophages from $L^{-/} / A^{-1-}$ mice was Pg dosedependent and decreased with the addition of active site-inactivated Pg or Pm inhibitors. Additionally, uptake of (ox)LDL from $\mathrm{L}^{-/-} / \mathrm{A}^{-/-} / \mathrm{Plg}^{-/-}$mice by macrophages from $\mathrm{L}^{-/-} / \mathrm{A}^{-/-} / \mathrm{Plg}^{-/-}$mice was significantly reduced compared with $\mathrm{L}^{-/-} / \mathrm{A}^{-/-}$mice. These results indicated that Pm activity played an important role in the modification of LDL and the uptake of (ox)LDL by macrophages, although there was a possibility that the results might be due to oxidized phospholipids because Pg in the circulation in vivo was a sink for oxidized phospholipids. Furthermore, higher plasma levels of TC, VLDL-C, and LDL-C were not triggered by hyper-hepatic synthesis of VLDL, which strongly implies that LDL metabolism itself was also downregulated by a Pg deficiency.

The major apolipoprotein in LDL is apoB100 in humans. Trypsin and Pm were able to cleave apoB100 in LDL. Consequently, small peptides were released from the LDL particle [32-34]. These enzymatically modified LDLs (ELDL) induced foam cell formation in macrophages [17], stimulated MCP-1 production [35], and promoted the adhesion of monocytes to the endothelial cell layer [36]. Moreover, ELDL formed by Pm was taken up more readily by human macrophages than murine macrophages [18]. 
There are four SRs that bind to modified LDL identified in macrophages [37]. Among them, SR-AI/II and CD36 are thought to be important for uptake of modified LDL [38]. In this study, RNA sequencing revealed that $C d 36$ expression by liver in $\mathrm{L}^{-/-} / \mathrm{A}^{-/-} / \mathrm{Plg}^{-/-}$ mice was diminished. It is thought that most of the signal was derived from hepatocytes. In the liver, there were two types of macrophages, namely, recruited and resident. Cd36 expression in both cell types was also diminished in $\mathrm{L}^{-1-} / \mathrm{A}^{-1-} / \mathrm{Plg}^{-/-}$mice. Interestingly, resident macrophages expressed more $C d 36$ than recruited macrophages, so macrophage might respond differently to the uptake of modified LDL, depending on the stage of differentiation. The downregulation of $\mathrm{Cd} 36$ in $\mathrm{Apoe}^{-/-} / \mathrm{Plg}^{-/-}$mice has also been previously reported in the literature [39]. The same authors also reported that foam cell formation of the macrophages prepared from $\mathrm{Apoe}^{-/-} / \mathrm{Plg}^{-/-}$mice by human oxLDL was diminished [39]. However, this could be contradictory to the initial characterization of the mice [15]. Moreover, it was reported that loss of receptor-mediated lipid uptake via SR$\mathrm{AI} / \mathrm{II}$ or CD36 pathways did not ameliorate atherosclerosis. It was also reported that it did not ameliorate loss of SR-AI/II, and CD36 did not abrogate foam cell formation in Apoe ${ }^{-/-}$ mice $[40,41]$. Preparation of murine LDL is difficult and human LDL/oxLDL is used in in vitro experiments with murine macrophages in many cases. We have speculated that the interaction between the C-terminus of apoB100 and $\mathrm{Pg}$ is key to explain some discrepancies in $A p o e^{-/-}$mice experiments. Consequently, we have developed $\mathrm{L}^{-/-} / \mathrm{A}^{-/-} / \mathrm{Cd} 36^{-/-}$and $\mathrm{L}^{-/-} / \mathrm{A}^{-/-} / \mathrm{Msr}^{-/-}$mouse lines and are now evaluating them. Moreover, it was reported that the gene expression levels of $C d 68$ (related to lipid uptake), Abca1 (related to phagocytosis), and Pparg (related to nuclear receptors) in $\mathrm{Apoe}^{-/-} / \mathrm{Plg}^{-/-}$mice were significantly more reduced than those in $A p o e^{-/-}$mice [39]. However, those in macrophages from $\mathrm{L}^{-/-} / \mathrm{A}^{-/-}$and $\mathrm{L}^{-/-} / \mathrm{A}^{-/-} / \mathrm{Plg}^{-/-}$mice were not significantly different.

In conclusion, we showed that $\mathrm{Pg} / \mathrm{Pm}$ accelerated foam cell formation in an apoB100positive, LDL-C-dominant murine model by enhancing uptake of oxLDL, likely modifying apoB100. The most common hypercholesterolemia in humans is type IIa, in which LDL containing apoB100 is dominant. The methods of preventing foam cell formation are clinically important, but this idea has not been put to practical use to treat atherosclerosis in humans. More recently, it was reported that there is a novel Pg receptor-Plg- $\mathrm{R}_{\mathrm{KT}}-$ which is an integral membrane protein that exposes a C-terminal Lys residue on this receptor in macrophages [42,43], and that $\mathrm{Pg}$ on macrophages accelerated wound healing [44]. Furthermore, overexpression of uPA in macrophages of $\mathrm{Apoe}^{-/-}$mice resulted in acceleration of atherosclerosis [45], and cholesterol efflux from macrophages was upregulated by $\mathrm{Pg}$ [46]. Therefore, not only scavenger receptors, but also their ligands and other receptors related to $\mathrm{Pg}$, as well as $\mathrm{Pg}$ activation system on macrophages, need to be investigated in $L^{-/} / A^{-/-}$mice.

Supplementary Materials: The following are available online at https:/ /www.mdpi.com/article/10 .3390 /biomedicines9121832/s1, Table S1: Primers and probes for genotyping of interbred mice with combined deficiencies of $L d l r$, Apobec1, and Plg.

Author Contributions: T.I., T.A., M.J.S.-C., D.L.S., and D.D. performed experiments; T.I. and T.A. analyzed the results and made the figures; T.I., V.A.P., K.U., and F.J.C. designed the research and wrote the paper. All authors have read and agreed to the published version of the manuscript.

Funding: This work was supported in part by the Japan Society for the Promotion of Science (JSPS) KAKENHI 20890093, 22790247, and 17K10666 (to T.I.), the Uehara Memorial Foundation (to T.I.), the "Translational Research Network Program" from Japan Agency for Medical Research and Development (AMED) 15lm0103009j0004 (to T.I.), the Health Labor Sciences Research Grant for Research on Measures for Intractable Diseases H27NN018B2 (to T.I.), HUSM Grant-in-Aid (to T.I.), and the National Institutes of Health (NHLBI) HL-073750 (to F.J.C.).

Institutional Review Board Statement: All animal experiments were approved by the Institutional Animal Care and Use Committee (IACUC) of the University of Notre Dame and Hamamatsu University School of Medicine.

Informed Consent Statement: Not applicable. 
Data Availability Statement: The data presented in this study are available on request from the corresponding author.

Acknowledgments: We acknowledge Stacey Raje, Patty Skibbins, and Angelik Andersen of the Freimann Life Sciences Center at the University of Notre Dame, and Kimiko Hara and Yasuhiro Kinpara of the department of pharmacology at the Hamamatsu University School of Medicine for their expert maintenance of the mouse colonies.

Conflicts of Interest: The authors declare no conflict of interest.

\section{References}

1. Chiang, J. Liver physiology: Metabolism and detoxification. In Pathobiology of Human Disease; McManus, L.M., Mitchell, R.N., Eds.; Academic Press: San Diego, CA, USA, 2014; pp. 1770-1782.

2. Kumar, V.; Butcher, S.J.; Oorni, K.; Engelhardt, P.; Heikkonen, J.; Kaski, K.; Ala-Korpela, M.; Kovanen, P.T. Three-dimensional cryoEM reconstruction of native LDL particles to 16A resolution at physiological body temperature. PLoS ONE 2011, 6, e18841. [CrossRef]

3. Plump, A.S.; Smith, J.D.; Hayek, T.; Aalto-Setala, K.; Walsh, A.; Verstuyft, J.G.; Rubin, E.M.; Breslow, J.L. Severe hypercholesterolemia and atherosclerosis in apolipoprotein E-deficient mice created by homologous recombination in ES cells. Cell 1992, 71, 343-353. [CrossRef]

4. Zhang, S.H.; Reddick, R.L.; Piedrahita, J.A.; Maeda, N. Spontaneous hypercholesterolemia and arterial lesions in mice lacking apolipoprotein E. Science 1992, 258, 468-471. [CrossRef]

5. Ishibashi, S.; Brown, M.S.; Goldstein, J.L.; Gerard, R.D.; Hammer, R.E.; Herz, J. Hypercholesterolemia in low density lipoprotein receptor knockout mice and its reversal by adenovirus-mediated gene delivery. J. Clin. Investig. 1993, 92, 883-893. [CrossRef] [PubMed]

6. Higuchi, K.; Kitagawa, K.; Kogishi, K.; Takeda, T. Developmental and age-related changes in apolipoprotein B mRNA editing in mice. J. Lipid Res. 1992, 33, 1753-1764. [CrossRef]

7. Powell-Braxton, L.; Veniant, M.; Latvala, R.D.; Hirano, K.I.; Won, W.B.; Ross, J.; Dybdal, N.; Zlot, C.H.; Young, S.G.; Davidson, N.O. A mouse model of human familial hypercholesterolemia: Markedly elevated low density lipoprotein cholesterol levels and severe atherosclerosis on a low-fat chow diet. Nat. Med. 1998, 4, 934-938. [CrossRef]

8. Miyajima, C.; Iwaki, T.; Umemura, K.; Ploplis, V.A.; Castellino, F.J. Characterization of atherosclerosis formation in a murine model of type IIa human familial hypercholesterolemia. Biomed Res. Int. 2018, 2018, 1878964. [CrossRef] [PubMed]

9. Mayer, M. Biochemical and biological aspects of the plasminogen activation system. Clin. Biochem. 1990, 23, 197-211. [CrossRef]

10. Castellino, F.J.; McCance, S.G. The kringle domains of human plasminogen. Ciba Found. Symp. 1997, 212, 46-60. [CrossRef]

11. Bhattacharya, S.; Ploplis, V.A.; Castellino, F.J. Bacterial plasminogen receptors utilize host plasminogen system for effective invasion and dissemination. J. Biomed. Biotechnol. 2012, 2012, 482096. [CrossRef]

12. Miles, L.A.; Hawley, S.B.; Baik, N.; Andronicos, N.M.; Castellino, F.J.; Parmer, R.J. Plasminogen receptors: The sine qua non of cell surface plasminogen activation. Front. Biosci. 2005, 10, 1754-1762. [CrossRef]

13. Urano, T.; Castellino, F.J.; Suzuki, Y. Regulation of plasminogen activation on cell surfaces and fibrin. J. Thromb. Haemost. 2018, 16, 1487-1497. [CrossRef] [PubMed]

14. Bini, A.; Fenoglio, J.J., Jr.; Mesa-Tejada, R.; Kudryk, B.; Kaplan, K.L. Identification and distribution of fibrinogen, fibrin, and fibrin(ogen) degradation products in atherosclerosis. Use of monoclonal antibodies. Arteriosclerosis 1989, 9, 109-121. [CrossRef]

15. Xiao, Q.; Danton, M.J.; Witte, D.P.; Kowala, M.C.; Valentine, M.T.; Bugge, T.H.; Degen, J.L. Plasminogen deficiency accelerates vessel wall disease in mice predisposed to atherosclerosis. Proc. Natl. Acad. Sci. USA 1997, 94, 10335-10340. [CrossRef] [PubMed]

16. Seifert, P.S.; Hugo, F.; Tranum-Jensen, J.; Zahringer, U.; Muhly, M.; Bhakdi, S. Isolation and characterization of a complementactivating lipid extracted from human atherosclerotic lesions. J. Exp. Med. 1990, 172, 547-557. [CrossRef] [PubMed]

17. Bhakdi, S.; Dorweiler, B.; Kirchmann, R.; Torzewski, J.; Weise, E.; Tranum-Jensen, J.; Walev, I.; Wieland, E. On the pathogenesis of atherosclerosis: Enzymatic transformation of human low density lipoprotein to an atherogenic moiety. J. Exp. Med. 1995, 182, 1959-1971. [CrossRef]

18. Torzewski, M.; Suriyaphol, P.; Paprotka, K.; Spath, L.; Ochsenhirt, V.; Schmitt, A.; Han, S.R.; Husmann, M.; Gerl, V.B.; Bhakdi, S.; et al. Enzymatic modification of low-density lipoprotein in the arterial wall: A new role for plasmin and matrix metalloproteinases in atherogenesis. Arterioscler. Thromb. Vasc. Biol. 2004, 24, 2130-2136. [CrossRef]

19. May, A.E.; Schmidt, R.; Bulbul, B.O.; Holderle, M.; Walther, F.; Schomig, A.; Gawaz, M.; Klouche, M. Plasminogen and matrix metalloproteinase activation by enzymatically modified low density lipoproteins in monocytes and smooth muscle cells. Thromb. Haemost. 2005, 93, 710-715. [CrossRef]

20. Ploplis, V.A.; Carmeliet, P.; Vazirzadeh, S.; Van Vlaenderen, I.; Moons, L.; Plow, E.F.; Collen, D. Effects of disruption of the plasminogen gene on thrombosis, growth, and health in mice. Circulation 1995, 92, 2585-2593. [CrossRef]

21. Hirano, K.; Young, S.G.; Farese, R.V., Jr.; Ng, J.; Sande, E.; Warburton, C.; Powell-Braxton, L.M.; Davidson, N.O. Targeted disruption of the mouse apobec-1 gene abolishes apolipoprotein B mRNA editing and eliminates apolipoprotein B48. J. Biol. Chem. 1996, 271, 9887-9890. [CrossRef] 
22. Iwaki, T.; Ploplis, V.A.; Castellino, F.J. The hemostasis system in murine atherosclerosis. Curr. Drug Targets 2008, 9, $229-238$. [CrossRef]

23. Iwaki, T.; Sandoval-Cooper, M.J.; Brechmann, M.; Ploplis, V.A.; Castellino, F.J. A fibrinogen deficiency accelerates the initiation of LDL cholesterol-driven atherosclerosis via thrombin generation and platelet activation in genetically predisposed mice. Blood 2006, 107, 3883-3891. [CrossRef]

24. Van der Hoogt, C.C.; Berbee, J.F.; Espirito Santo, S.M.; Gerritsen, G.; Krom, Y.D.; van der Zee, A.; Havekes, L.M.; van Dijk, K.W.; Rensen, P.C. Apolipoprotein CI causes hypertriglyceridemia independent of the very-low-density lipoprotein receptor and apolipoprotein CIII in mice. Biochim. Biophys. Acta 2006, 1761, 213-220. [CrossRef]

25. Iwaki, T.; Malinverno, C.; Smith, D.; Xu, Z.; Liang, Z.; Ploplis, V.A.; Castellino, F.J. The generation and characterization of mice expressing a plasmin-inactivating active site mutation. J. Thromb. Haemost. 2010, 8, 2341-2344. [CrossRef] [PubMed]

26. Bourgognon, M.; Klippstein, R.; Al-Jamal, K.T. Kupffer cell isolation for nanoparticle toxicity testing. J. Vis. Exp. 2015, 18, e52989. [CrossRef] [PubMed]

27. Kosaka, S.; Takahashi, S.; Masamura, K.; Kanehara, H.; Sakai, J.; Tohda, G.; Okada, E.; Oida, K.; Iwasaki, T.; Hattori, H.; et al. Evidence of macrophage foam cell formation by very low-density lipoprotein receptor: Interferon-gamma inhibition of very low-density lipoprotein receptor expression and foam cell formation in macrophages. Circulation 2001, 103, 1142-1147. [CrossRef] [PubMed]

28. Henriksen, T.; Mahoney, E.M.; Steinberg, D. Enhanced macrophage degradation of biologically modified low density lipoprotein. Arteriosclerosis 1983, 3, 149-159. [CrossRef]

29. Steinbrecher, U.P.; Parthasarathy, S.; Leake, D.S.; Witztum, J.L.; Steinberg, D. Modification of low density lipoprotein by endothelial cells involves lipid peroxidation and degradation of low density lipoprotein phospholipids. Proc. Natl. Acad. Sci. USA 1984, 81, 3883-3887. [CrossRef]

30. Quinn, M.T.; Parthasarathy, S.; Fong, L.G.; Steinberg, D. Oxidatively modified low density lipoproteins: A potential role in recruitment and retention of monocyte/macrophages during atherogenesis. Proc. Natl. Acad. Sci. USA 1987, 84, 2995-2998. [CrossRef]

31. Xu, N.; Dahlback, B.; Ohlin, A.K.; Nilsson, A. Association of vitamin K-dependent coagulation proteins and C4b binding protein with triglyceride-rich lipoproteins of human plasma. Arterioscler. Thromb. Vasc. Biol. 1998, 18, 33-39. [CrossRef]

32. Chapman, M.J.; Millet, A.; Lagrange, D.; Goldstein, S.; Blouquit, Y.; Taylaur, C.E.; Mills, G.L. The surface-exposed, trypsinaccessible segments of apolipoprotein B in the low-density lipoprotein of human serum. Fractionation and characterisation of the liberated peptides. Eur. J. Biochem. 1982, 125, 479-489. [CrossRef]

33. Coetzee, G.A.; Gevers, W.; van der Westhuyzen, D.R. Plasmin-treated low density lipoproteins: Polypeptide analyses and metabolism by cultured smooth muscle cells. Artery 1980, 7, 1-15.

34. Cardin, A.D.; Witt, K.R.; Chao, J.; Margolius, H.S.; Donaldson, V.H.; Jackson, R.L. Degradation of apolipoprotein B-100 of human plasma low density lipoproteins by tissue and plasma kallikreins. J. Biol. Chem. 1984, 259, 8522-8528. [CrossRef]

35. Klouche, M.; Gottschling, S.; Gerl, V.; Hell, W.; Husmann, M.; Dorweiler, B.; Messner, M.; Bhakdi, S. Atherogenic properties of enzymatically degraded LDL: Selective induction of MCP-1 and cytotoxic effects on human macrophages. Arterioscler. Thromb. Vasc. Biol. 1998, 18, 1376-1385. [CrossRef] [PubMed]

36. Klouche, M.; May, A.E.; Hemmes, M.; Messner, M.; Kanse, S.M.; Preissner, K.T.; Bhakdi, S. Enzymatically modified, nonoxidized LDL induces selective adhesion and transmigration of monocytes and T-lymphocytes through human endothelial cell monolayers. Arterioscler. Thromb. Vasc. Biol. 1999, 19, 784-793. [CrossRef]

37. Kunjathoor, V.V.; Febbraio, M.; Podrez, E.A.; Moore, K.J.; Andersson, L.; Koehn, S.; Rhee, J.S.; Silverstein, R.; Hoff, H.F.; Freeman, M.W. Scavenger receptors class A-I/II and CD36 are the principal receptors responsible for the uptake of modified low density lipoprotein leading to lipid loading in macrophages. J. Biol. Chem. 2002, 277, 49982-49988. [CrossRef] [PubMed]

38. Pluddemann, A.; Neyen, C.; Gordon, S. Macrophage scavenger receptors and host-derived ligands. Methods 2007, 43, 207-217. [CrossRef] [PubMed]

39. Das, R.; Ganapathy, S.; Mahabeleshwar, G.H.; Drumm, C.; Febbraio, M.; Jain, M.K.; Plow, E.F. Macrophage gene expression and foam cell formation are regulated by plasminogen. Circulation 2013, 127, 1209-1218. [CrossRef]

40. Moore, K.J.; Kunjathoor, V.V.; Koehn, S.L.; Manning, J.J.; Tseng, A.A.; Silver, J.M.; McKee, M.; Freeman, M.W. Loss of receptormediated lipid uptake via scavenger receptor A or CD36 pathways does not ameliorate atherosclerosis in hyperlipidemic mice. $J$. Clin. Investig. 2005, 115, 2192-2201. [CrossRef] [PubMed]

41. Manning-Tobin, J.J.; Moore, K.J.; Seimon, T.A.; Bell, S.A.; Sharuk, M.; Alvarez-Leite, J.I.; de Winther, M.P.; Tabas, I.; Freeman, M.W. Loss of SR-A and CD36 activity reduces atherosclerotic lesion complexity without abrogating foam cell formation in hyperlipidemic mice. Arterioscler. Thromb. Vasc. Biol. 2009, 29, 19-26. [CrossRef] [PubMed]

42. Andronicos, N.M.; Chen, E.I.; Baik, N.; Bai, H.; Parmer, C.M.; Kiosses, W.B.; Kamps, M.P.; Yates, J.R., 3rd; Parmer, R.J.; Miles, L.A. Proteomics-based discovery of a novel, structurally unique, and developmentally regulated plasminogen receptor, Plg-RKT, a major regulator of cell surface plasminogen activation. Blood 2010, 115, 1319-1330. [CrossRef] [PubMed]

43. Lighvani, S.; Baik, N.; Diggs, J.E.; Khaldoyanidi, S.; Parmer, R.J.; Miles, L.A. Regulation of macrophage migration by a novel plasminogen receptor Plg-R KT. Blood 2011, 118, 5622-5630. [CrossRef] [PubMed]

44. Shen, Y.; Guo, Y.; Mikus, P.; Sulniute, R.; Wilczynska, M.; Ny, T.; Li, J. Plasminogen is a key proinflammatory regulator that accelerates the healing of acute and diabetic wounds. Blood 2012, 119, 5879-5887. [CrossRef] [PubMed] 
45. Kremen, M.; Krishnan, R.; Emery, I.; Hu, J.H.; Slezicki, K.I.; Wu, A.; Qian, K.; Du, L.; Plawman, A.; Stempien-Otero, A.; et al. Plasminogen mediates the atherogenic effects of macrophage-expressed urokinase and accelerates atherosclerosis in apoE-knockout mice. Proc. Natl. Acad. Sci. USA 2008, 105, 17109-17114. [CrossRef]

46. Pamir, N.; Hutchins, P.M.; Ronsein, G.E.; Wei, H.; Tang, C.; Das, R.; Vaisar, T.; Plow, E.; Schuster, V.; Koschinsky, M.L.; et al. Plasminogen promotes cholesterol efflux by the ABCA1 pathway. JCI Insight 2017, 2, e92176. [CrossRef] 